\title{
COMPARATIVE ASSESSMENT OF QUALITY \\ OF THE INGULETS AND DNIPRO IRRIGATION WATER USING THE METHOD OF CLUSTER ANALYSIS
}

\section{Biliaieva I. M., Lykhovyd P. V.}

\section{INTRODUCTION}

Irrigation under the conditions of increasing aridity of the climate is a decisive measure of intensification of agricultural production in the Steppe zone of Ukraine. In recent decades, global environmental threats have intensified on the Earth, including climate change, desertification, and biodiversity loss, which are destroying natural resources and endangering mankind existence. In Ukraine, these threats are no less dangerous, especially climate change, which is manifested by severe droughts in the south, as well as floods in the western regions. Besides, an extremely important problem is soil degradation, which affects not only the yield and quality of crop products, but also causes significant economic losses on the regional and state levels ${ }^{1,2}$.

Food security, economic and environmental aspects depend to a large extent on the efficient use and preservation of the irrigated lands. In the arid regions of the world, including the Southern Steppe of Ukraine, the most effective and reliable measure to stabilize agriculture is artificial humidification, which stabilizes crop productivity and prevents a catastrophic decline in gross crop yields in the years with adverse weather conditions (no precipitation, high air temperature, dry winds, etc. $)^{3,4,5,6}$.

1 Оцінка і прогноз якості земель: навчальний посібник / С. Ю. Булигін, А. В. Барвінський, А. О. Ачасова, А. Б. Ачасов. Харків : Вища школа, 2008. 237 с.

2 Удобрення польових культур при інтенсивних технологіях вирощування / за ред. А. Я. Буки, Г. Г. Дуди. К. : Урожай, 1990. 208 с.

3 Водне господарство в Україні / За ред. А.В. Яцика, В.М. Хорєва. К.: Генеза, 2000. 456 с.

${ }^{4}$ Грунтознавство / за ред. Д. Г. Тихоненка. К., 2005. С. 122-127.

5 ДСТУ 4289:2004. Якість грунту. Методи визначання органічної речовини.

6 Кисель В. Д. О генезисе солонцеватых почв Украины. Почвоведение. 1981. № 12. С. 10-12. 
As an open system, the soil is dynamic and is in constant interaction with the atmosphere, hydrosphere, biosphere and lithosphere. Depending on the intensity of these factors' action, the soil may present differentiated characteristics that determine their potential for human exploitation ${ }^{7}$. Although soil structure is not considered as a factor of plant growth, it affects the air and water supply of root systems, the availability of nutrients, the activity of microorganisms and so on. It is also associated with the loss of agrochemicals due to water and wind erosion, which has a negative impact on the environment through the use of intensive technologies for cereals, vegetables and other crops cultivation. The quality of irrigation water must meet agronomic, environmental, technical, sanitary and hygienic requirements ${ }^{8}$.

Mineralization and chemical composition of irrigation water can create a risk of salinization, alkalization, soda formation in the soil, adversely affect crop yields and the quality of crop products and the preservation of irrigation constructions. Therefore, a certain content of chlorine, sodium, magnesium, and carbonate ions in water is established ${ }^{9}$. The main threats to the soil are erosion, mineralization of organic matter, reduction of biological diversity, pollution, waterproofing, compaction, salinization, and degrading effects of floods and landslides ${ }^{10,11}$.

The resistance of crops to the irrigation water mineralization depends on the type of plants, the stage of their development, soil moisture. Saltresistant crops reduce yields when mineralization is more than $2.5 \mathrm{~g} / \mathrm{L}$, moderately resistant - more than 1.4 , slightly resistant $-0.8 \mathrm{~g} / \mathrm{L}$. The most resistant to mineralization are wheat, rye, barley, sugar and fodder beets, cotton-plant, soybeans; slightly resistant ones are legumes, potatoes, vegetables, fruits and berries.

Occurrence of salinity, toxicity of soils creates problems in the reduction of crop yields, and also limits the set of crops in crop rotations.

7 Балабанова Л. В. SWOT-аналіз - основа формування маркетингових стратегій: Навчальний посібник. 2-ге вид., випр. і доп. (Вища освіта XXI ст.) К. : Знання, 2005. 301 с.

${ }^{8}$ Сидоренко О. І., Бабанін В. В., Морозов О. В. Еколого-агромеліоративний моніторинг зрошуваних земель. Херсон : Колос, 2013. 152 с.

9 Справочник агрогидрологических свойств почв Украинской ССР / под ред. А. А. Мороз. Ленинград: Гидрометеорологическое издательство, 1965. 550 с.

${ }^{10}$ Коваленко П. І., Михайлов Ю. О. Раціональне використання води при зрошенні. К. : Аграрна наука, 2000. 215 с.

11 Медведєв В. В., Чесняк Г. Я., Полупан М. І. та ін.Родючість грунтів: моніторинг та управління. К. : Урожай, 1992. 248 с. 
Therefore, it is extremely important to support agro-production to minimize salinization and deterioration of soil physical conditions over the long term use. This has led to the replacement of conservative standards for determining water quality through guidelines for specific areas, to new ones, where the appropriate choice of crops, improved water management, maintenance of soil structure is necessary ${ }^{12}$.

Of the world's 1.5 billion hectares of arable land, 77 million hectares (5\%) are unable to produce high and qualitative crops due to high salt content, and $20 \%$ of irrigated agricultural land is negatively affected by excessive salt content. Soil salinization is steadily increasing on all continents, in particular, in arid and semi-arid areas, which cover more than $7 \%$ of the total land surface on the Earth ${ }^{13}$.

Salt stress is considered to be a major factor limiting crop productivity. On saline soils, plant growth sharply decreases, mainly due to osmotic stress. Low water potential in the roots causes water deficiency in the plant ${ }^{14}$.

Toxic concentrations of $\mathrm{Na}^{+}$and $\mathrm{Cl}^{-}$ions in plants affect the functions of cell membranes. Large amounts of these ions also reduce metabolic activity in plants and lead to inhibition of growth processes and damage to leaves. In addition, salt stress causes nutrient imbalances and oxidative stress in plants, which hinders proper growth and development. The high content of water-soluble salts in the upper layers of soils causes a significant decrease in crop yields and crop quality and requires the development and implementation of methods to improve soil fertility and prevent their degradation ${ }^{15}$.

Water is one of the most important and scarce resources for agricultural production in the arid and semi-arid areas. Improving productivity in the arid regions strongly depends on the practice of rational irrigation management, taking into account rainwater and

12 Методические указания по определению нитрификационной способности почв. М. : ВПНО «Сельхозхимия», 1984. 16 с.

13 Жигулина Е. В., Максименко В. П., Волчкова Т. Л. Повышение плодородия почв на орошаемых землях. Методы и технологии комплексной мелиорации и экосистемного водопользования : Сб. науч. трудов / Под ред. акад. РАСХН Б. М. Кизяева. М. : Россельхозакадемия, 2006. С. 426-442.

14 Тимчук В. М. Моніторинг ринку об'єктів права інтелектуальної власності в галузі рослинництва. Вісник аграрної науки. 2007. №10. С. 30-32.

${ }_{5}$ Кудеяров В. Н., Башкин В. Н., Кудеярова А. Ю., Бочкарев А. Н. Экологические проблемы применения минеральных удобрений. М. : Наука, 1984. 214 c. 
groundwater status ${ }^{16}$. The lack of sufficient water supplies for irrigated agriculture at the present stage is becoming a significant problem, forcing farmers to use water of low quality. However, reckless use of sodium and salt water poses a danger to the physical, chemical and biological properties of the soil.

One of the main sources of irrigation of meliorated lands in the south of Ukraine is the system of irrigation waters from the Ingulets River, which is characterized by unstable hydrological and hydrochemical regimes.

Discharge of industrial waters of Kryvbas into the Ingulets River significantly increases mineralization and worsens the chemical composition of the water. During the growing season in the area of Kryvyi Rih Ingulets water is formed exclusively due to unregulated discharge of wastewater. As a result of these processes, irrigation with the Ingulets water is almost unsuitable according to irrigation indices without appropriate amelioration measures ${ }^{17,18,19}$.

The waters of the Dnipro River are no less significant for the southern agricultural lands of Ukraine. In terms of mineralized composition, it is more suitable for irrigation, but recently the pollution of the Dnipro waters with toxicants has increased, the groundwater level has risen far from the shores, soil salinity has increased, groundwater volume has increased almost 10 times, and at the same time, especially in the lower part of the basin, the water-salt regime of the soils in the irrigation zones has changed, the humus content has decreased ${ }^{20,21}$. Therefore, research in the field of analysis and dynamics of the mineralized composition of the Ingulets and Dnipro irrigation waters for the further use of this knowledge in agricultural production is relevant today.

${ }^{16}$ Ковда В. А. Происхождение и режим засоленных почв. М.-Л. : АН СССР, 1979. C. 52-59.

${ }^{17}$ Балюк С. А., Верніченко Г. А. Концепція екологічного ризику деградації грунтового покриву України. Вісник аграрної науки. 2002. № 6. С. 5-11.

18 Грунтознавство 3 основами геології : [навч. посіб] / О. Ф. Ігнатенко, М. В. Капштик, Л. Р. Петренко, С. В. Вітвицький. К. : Оранта, 2005. 648 с.

19 Справочник по орошаемому земледелию / под ред. В. И. Остапова. 2-е изд., перераб. и доп. К. : Урожай, 1989. 256 с.

20 Бендиков М. А., Джамалай Е. В. Интеллектуальный капитал развивающейся фирмы: проблемы идентификации и измерения. Менеджмент в России и за рубежом. 2001. № 4. С. 3-24.

${ }^{21}$ Качинский Н. А. Изучение физических свойств почв и корневых систем растений. М. : Сельхозгиз, 1930. 101 с. 


\section{Cluster analysis as a method of data sets analysis}

The set of methods and algorithms used for automatic grouping of data is called cluster analysis. Using cluster analysis to solve our problem is most effective because it is designed to combine some objects into classes (clusters) so that one class gets as similar as possible, and objects of different classes differ as much as possible from each other. Quantitative similarity is calculated in a given way on the basis of data characterizing the objects ${ }^{22}$.

Cluster analysis includes a wide range of data analysis methods, including k-means, hierarchical clustering, and two-way aggregation. The data can come both in the original form and in the form of a matrix of distances between the objects. Observations and variables can be clustered using different measures (Euclidean calculations, Euclidean square, urban quarters (Manhattan), Chebyshev, static, percentage of disagreement and 1-Pearson correlation coefficient) and different rules for combining clusters (single, full weighted, weighted and weighted pairwise group averages, weighted, weighted distance between centers, Ward method, etc.). Distance matrices can be stored for further analysis. When performing cluster analysis by the method of k-means, the user has full control over the initial location of the centers of the clusters. Extremely large volumes of analysis can be performed: for example, with hierarchical (tree-like) bonding, it is possible to work on a matrix of 90 thousand distances ${ }^{23}$.

In addition to the standard results of cluster analysis, a diverse set of descriptive statistics and advanced diagnostic methods are also available (complete scheme of integration with threshold levels in hierarchical clustering, table of analysis of variance in clustering by k-means). Information about the affiliation of objects to clusters can be added to the database and used in further analysis ${ }^{24}$.

Graphical capabilities of cluster analysis include customizable dendrograms, two-way association diagrams, graphical representation of association schemes, diagrams of averages when clustering by the method of k-means, taking into account the action and interaction of factors.

Cluster analysis includes a set of different classification algorithms. Also, this analysis allows solving scientific problems in many fields of

22 Салин В. Н. Социально-экономическая статистика: практикум / под ред. В. Н. Салина, Е. П. Шпаковской. М. : Финансы и статистика, 2012. 192 с.

${ }^{23}$ Сиденко А. В., Попов Г. Ю., Матвеева В. М. Статистика: учебник. М. : Изд-во «Дело и сервис», 2009. 464 с.

${ }^{24}$ Финансовая статистика: учеб. пособие / под ред. Т. В. Тимофеевой. М. : Финансы и статистика, 2008. 480 с. 
science with the organization of observations of complex systems. The clustering technique is used in a variety of areas. For example, in the field of medicine, clustering of diseases, treatment of diseases or symptoms of diseases makes it possible to carry out taxonomies that are widely used today ${ }^{25}$.

The association or method of tree clustering is used in the formation of clusters of differences or distances between objects. These distances can be determined in one-dimensional or multidimensional space. However, the aggregation algorithm does not "care" about whether the distances provided for this distance are real or some other derivative measures, which is more significant for the researcher; and the task of researchers is to choose the right method for specific applications ${ }^{26}$.

Single connection (nearest neighbor method). In this method, the distance between two clusters is determined by the distance between the two nearest objects (nearest neighbors) in different clusters. This rule should, in this sense, string objects together to form clusters, resulting in clusters tending to be represented by long "chains". Full communication (the method of the most distant neighbors). In this method, the distances between clusters are determined by the greatest distance between any two objects in different clusters (i.e., the most "distant neighbors").

This method usually works very well when objects are actually derived from really different structural elements. If the clusters have some kind of elongated shape or their natural type is chain, then this method is not suitable.

There are other methods used depending on the problems of the study, this is the method of two-way combination, Ward, weighted centroid method (median), weighted and unweighted pairwise mean ${ }^{27}$.

All the cluster algorithms require estimates of distances between clusters or objects, and it is clear that when calculating distances, it is necessary to specify the scale of measurements. Because different measurements use completely different types of scales, the data must be standardized so that each variable has a mean of 0 and a standard deviation of 1 . Analysis of statistical data on the cationic-anionic

25 Харченко О. В. Основи програмування врожаїв сільськогосподарських культур : навчальний посібник / за ред. академіка УААН В. О. Ушкаренка [2-е вид., перероб. і доп.]. Суми: Університетська книга, 2003. 296 с.

${ }^{26}$ Балюк С. А., Новікова Г. В., Гаврилович Н. Ю. Використання солонцевих грунтів України. Вісник аграрної науки. 2001. № 10. С. 12-15.

27 Дорогунцов С. І., Чернюк Л. Г., Борщевський П. П. Соціально-економічні системи продуктивних сил регіонів України. Рада по вивч. продукт. сил України НАН України. К. : Нічлава, 2002. 691 с. 
composition of irrigation water from the Ingulets and Dnipro rivers using clustering and correlation-regression analysis allowed to distribute all the years of the study and the indices of cationic-anionic composition of the water into cluster groups.

This work allowed to trace with a high level of accuracy the dynamics of changes and interdependencies in the complex system "irrigation water - soils - crops", to characterize the patterns of mineralized waters over the years and select them by the corresponding features for further use of this information in scientific work and in practice.

\section{Evaluation of the irrigation water quality by agronomic criteria from different sources}

\subsection{The Ingulets irrigation water analysis}

Irrigation productivity strongly depends on the quality of irrigation water, because if artificial humidification is carried out with the water of low quality (II or III classes), then instead of increasing crop yields it will provide a negative impact on plants' productivity. In addition, irrigation with low quality water will lead to deterioration and loss of soil fertility due to secondary salinization, degradation processes, crusting, compaction, etc. According to the results of laboratory analyzes of the laboratory of analytical research of the Institute of Irrigated Agriculture of NAAS it is established that irrigation water from the Ingulets irrigation system has a concentration of toxic ions in chlorine equivalents in the range of $25-42 \mathrm{meq} / \mathrm{dm}^{3}$, the ratio of sodium to alkaline cations was $41-47 \%$ (Table 1).

Table 1

Evaluation of the irrigation water (2008-2019)

\begin{tabular}{|c|c|c|c|c|c|c|c|c|c|}
\hline \multirow{2}{*}{$\begin{array}{l}\text { Date of } \\
\text { collecting } \\
\text { the sample }\end{array}$} & \multirow{2}{*}{$\begin{array}{c}\text { Mineralization, } \\
\mathrm{g} / \mathrm{dm}^{3}\end{array}$} & \multirow{2}{*}{$\begin{array}{l}\text { Toxic ions } \\
\text { concentration, } \\
\text { meq } / \mathrm{dm}^{3}\end{array}$} & \multirow{2}{*}{$\begin{array}{l}\frac{\mathrm{Na}^{+} \mathrm{x}}{100} \\
\begin{array}{l}\text { Sum of } \\
\text { cations }\end{array}\end{array}$} & \multirow{2}{*}{$\frac{\mathrm{Mg}^{2+}}{\mathrm{Ca}^{2+}}$} & \multirow{2}{*}{$\frac{\mathrm{Ca}^{2+}}{\mathrm{Na}^{+}}$} & \multicolumn{4}{|c|}{$\begin{array}{c}\text { Class of the water by the hazard } \\
\text { (DSTU-2730-94 "Water quality. Agronomic } \\
\text { criteria") }\end{array}$} \\
\hline & & & & & & salinization & $\begin{array}{l}\text { caustic } \\
\text { increase }\end{array}$ & alkalinization & $\begin{array}{c}\text { toxic } \\
\text { impact }\end{array}$ \\
\hline $\begin{array}{l}\text { III ten-day } \\
\text { period of } \\
\text { May }\end{array}$ & 1.809 & 42 & 42 & 1.4 & 0.2 & III & III & II & III \\
\hline $\begin{array}{l}\text { I ten-day } \\
\text { period of } \\
\text { July }\end{array}$ & 1.750 & 25 & 41 & 1.6 & 0.3 & II & III & II & II \\
\hline $\begin{array}{l}\text { II ten-day } \\
\text { period of } \\
\text { September }\end{array}$ & 1.580 & 25 & 47 & 1.8 & 0.2 & II & III & II & II \\
\hline
\end{tabular}


It should be mentioned that mineralization, concentration of toxic ions and other indices of irrigation water quality change significantly in different periods of the irrigation season, and the greatest values are reached in the initial stages of the irrigation season (III ten-day period of May) with further decrease in July and especially in September. Irrigation water quality control allows to classify it to the second class according to the degree of salinization and alkalinization hazards of middle-loamy low-buffer soils of the Ingulets irrigation system - it is limited suitable for irrigation in the summer-autumn period.

We performed correlation-regression, variance analysis in the Excel software package, and cluster analysis using the software-information complex Statistics 6.1 for the quality of the water for irrigation from the Ingulets and Dnipro rivers. According to the results of generalization of the experimental data, a number of statistical sample dependences, visual graphs, diagrams were formed, which allowed to draw a lot of useful conclusions for the use of the acquired knowledge in agro-ameliorative practice of crop production.

Statistica 6.1 software and information complex is a product of StatSoft Russia, an exclusive representative of the American company StatSoft Inc. (Part of Dell) in Ukraine and other countries. At present, StatSoft is one of the world's largest developers of statistical and analytical software, offering a wide range of analytical and consulting services in various applications for data analysis ${ }^{28,29}$. The input data for calculations in the program Statistica can be data prepared in various specialized or utility programs: Microsoft Office (Word, Access, Excel) and web-applications ${ }^{30}$. We collected material on the characteristics of the mineralized composition of the Ingulets and Dnipro water, formed databases, which are presented in the spreadsheets of Excel (Fig. 1) according to the growing seasons as of 15.05, 15.07 and 15.09 for 1973-2019 years of the research. After importing data from Excel to Statistica, the information in the tables should be standardized, as shown in the Figure 2.

28 Балюк С. А. Внесення мінеральних добрив і меліорантів 3 водою при дощуванні. Довідник працівника агрохімслужби / за ред. Б. С. Носкова. К. : Урожай, 1991. С. 100-104.

29 Біляєва I. М. Наукове обгрунтування систем удобрення зрошуваних агрофітоценозів 3 моделюванням вмісту органічних та неорганічних сполук. Матеріали Міжнародної науково-практичної конференції «Управління водними ресурсами в умовах змін клімату», присвяченої Всесвітньому дню води (21 березня 2017 р.). К. : ЦП «КОМПРИНТ», 2017. С. 156-157.

30 Григоров М. С. Высокоэффективное внутрипочвенное орошение. Известия Нижневолжского агроуниверситетского комплекса. 2010. № 1(17). C. 3-5. 


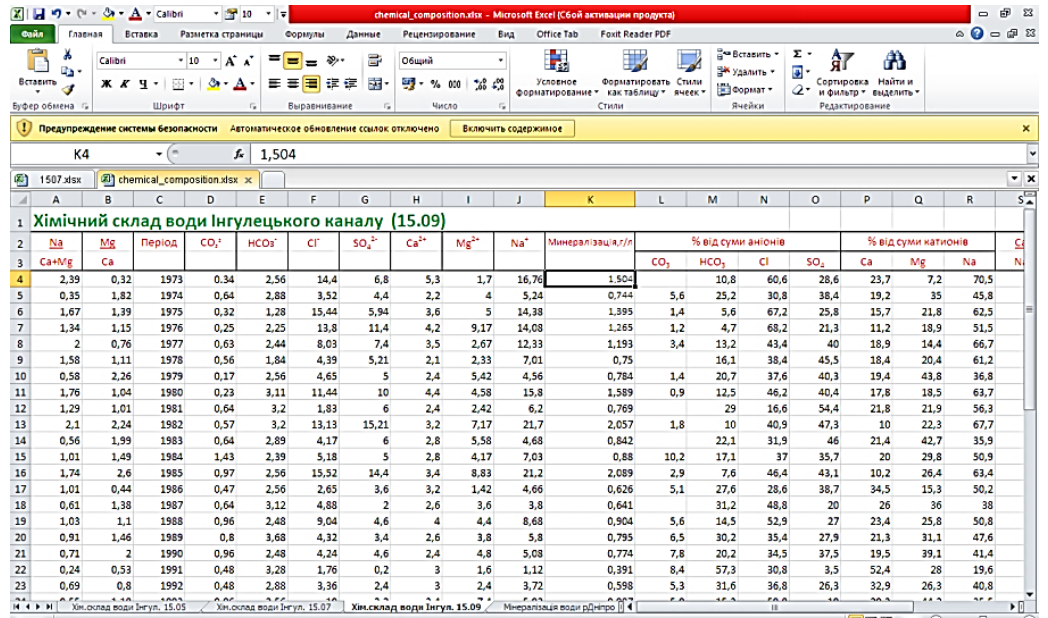

Fig. 1. Copy of the screen of the Excel table with information on the ionic-cationic composition of the irrigation water from the Ingulets River as of 15.09 for the period of 1973-2019

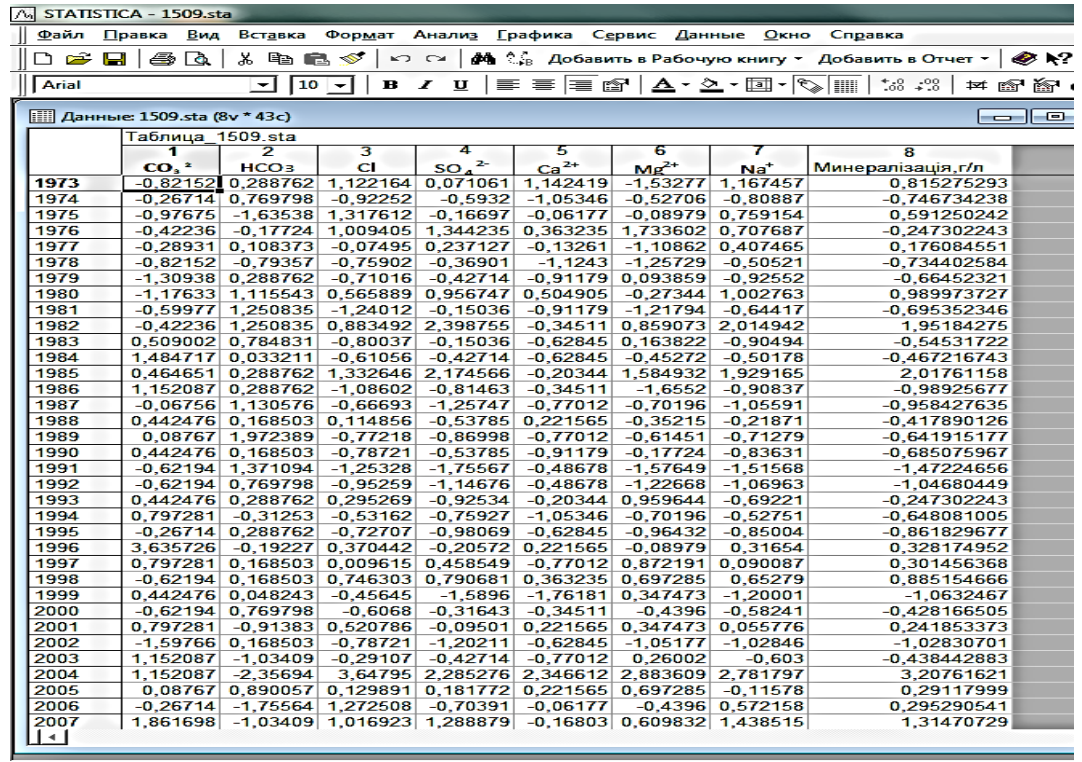

Fig. 2. The standardized data of the table of mineralization indices as of $\mathbf{1 5 . 0 9}$ for the period from 1973 to 2019 
Next, we begin to form a hierarchical classification of cluster analysis using the interactive mode in Statistica: "Cluster analysis" - menu "Analysis" - "Multidimensional exploration analysis" to display the start panel of the module "Cluster analysis" "Hierarchical classification".

To form a hierarchical diagram of cluster analysis, we choose the method of full communication, which determines the distance between clusters as the largest distance between any two objects in different clusters (i.e. the most distant positions). At the output we get a hierarchical tree for analysis (Fig. 3.)

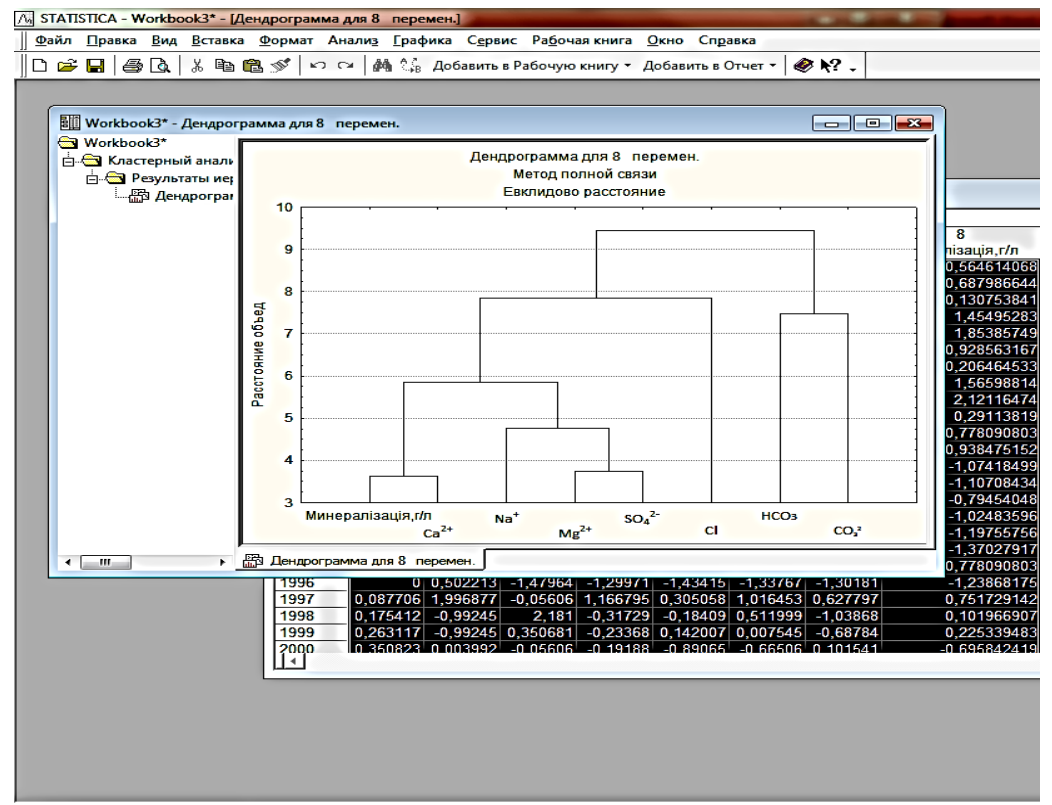

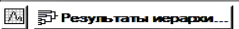

Fig. 3. Hierarchical model of cluster analysis of the chemical composition of the Ingulets irrigation water as of 15.09 for the period from 1973 to 2019

Based on the obtained data, clusters are formed, which are created from top to bottom for the vertical dendrogram. When moving from top to bottom, the indices that "are in closer contact with each other" combine and form clusters. Each node of the diagram, presented above, represents the union of two or more clusters, the position of the nodes on the vertical axis determines the distance at which the respective clusters were connected. 
As it has already been noted, the full connection method defines the distance between clusters as the greatest distance between any two objects in different clusters (i.e., "most distant neighbors"). The measure of proximity, which is determined by the Euclidean distance, is the geometric distance in n-dimensional space and is calculated by the formula (1):

$$
d(x, y)=\sqrt{\sum_{i-1}^{n}\left(x_{i}-y_{i}\right)^{2}}
$$

Analyzing the hierarchical clustering tree generated by the program, we can assume that the studied characteristics of the ionic-salt composition of the water is formed in 4 natural clusters ( 1 cluster mineralization, $\mathrm{Ca}^{2+} ; 2$ cluster $-\mathrm{Na}^{+}, \mathrm{Mg}^{2+}, \mathrm{SO}_{4}{ }^{2-} ; 3$ cluster $-\mathrm{Cl}^{-}$; 4 cluster $-\mathrm{HCO}_{3}{ }^{-}, \mathrm{CO}_{3}{ }^{2-}$ ).

Let us test this assumption by dividing the initial data by the k-means method into clusters, and check the significance of the differences between the obtained groups.

In the menu paragraph "Analysis" - "Multidimensional exploration analysis" of the starting module "Cluster analysis" in the dialog select "Clustering by the means" and set the necessary parameters for further formation. The method makes it possible to cluster objects or variables (in our case, observations) in order to cluster the cationic-anionic composition of irrigation water.

The initial number of clusters is set at level 4, because the results of the k-means method depend to some extent on the initial configuration (i.e. on the means or centers of the clusters). In particular, this occurs when many small, clearly separated clusters (with multiple objects) are formed.

As a result of the module operation we obtain the list of items with already formed data and graphs.

By the means of cluster analysis by the k-means method we can find intergroup dispersions according to the studied indices of the chemical composition of the irrigation water, which are compared with intragroup dispersions to decide whether the means for individual variables in different aggregates are significantly different. We can consider the results of the analysis of variance, comparing for each measurement the average (i.e. measurement of characteristics) between the sums (clusters) (Fig. 4). 
ANOVA (Table_1509.sta)

\begin{tabular}{|c|c|c|c|c|c|c|c|}
\hline & Intra & ce & Inside & cc & F & Signific. \\
\hline $\mathbf{C O}^{2-}$ & 18.22074 & 4 & 24.77926 & 49 & 9.96119 & 0.000052 \\
\hline $\mathbf{H C O}^{2-}$ & 11.14581 & 4 & 40.86419 & 49 & 4.69041 & 0.006844 \\
\hline $\mathbf{C l}$ & 25.41665 & 4 & 16.58445 & 49 & 19.92459 & 0.000000 \\
\hline $\mathbf{S O}^{-}{ }^{2-}$ & 40.89749 & 4 & 11.10251 & 49 & 46.17805 & 0.000000 \\
\hline $\mathbf{C a}^{2+}$ & 19.44948 & 4 & 22.65052 & 49 & 11.10541 & 0.000021 \\
\hline $\mathbf{M g}^{2+}$ & 19.27717 & 4 & 22.72284 & 49 & 11.02870 & 0.000022 \\
\hline $\mathbf{N a}^{+}$ & 44.78601 & 4 & 7.21499 & 49 & 62.68642 & 0.000000 \\
\hline Mineralization, $\mathbf{g} / \mathbf{L}$ & 42.10275 & 4 & 9.89725 & 49 & 42.16684 & 0.000000 \\
\hline
\end{tabular}

Fig. 4. A copy of the screen with the results of ANOVA of the chemical composition of the Ingulets water as of $\mathbf{1 5 . 0 9}$ for the period from 1973 to 2019

Based on the amplitude (and levels of significance) of F-statistics, the variables $\mathrm{Na}+$, mineralization, $\mathrm{SO} 42-$ and $\mathrm{Cl}$ - are the main in solving the question of the distribution of objects in clusters. The item "Elements of clusters and distances" deciphers which members (in our case years) each cluster consists of.

By the results of the ANOVA it is possible to conclude that for the data on the chemical composition of the irrigation water as of 15.05 the main variables in solving the question of distribution of objects in clusters were variables $\mathrm{CO}_{3}{ }^{2-}$, mineralization and $\mathrm{SO}_{4}{ }^{2-}$ (Fig. 5), and for the data on chemical composition of the irrigation water as of 15.07 indices of $\mathrm{Ca}^{2+}, \mathrm{SO}_{4}{ }^{2-}$ and mineralization (Fig. 6).

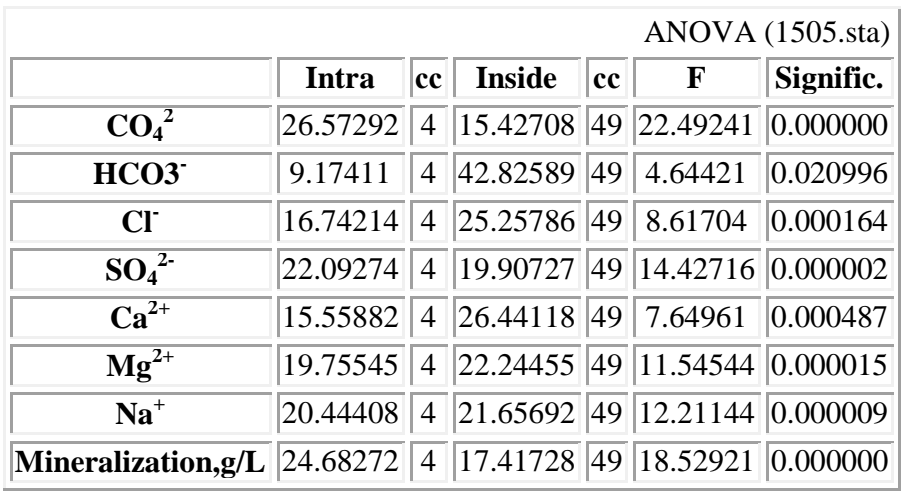

Fig. 5. A copy of the screen with the ANOVA results of the chemical composition of the Ingulets water as of 15.05 for the period from 1973 to 2019 
ANOVA (Table_0507.sta)

\begin{tabular}{|c|c|c|c|c|c|c|}
\hline & Intra & $\mathbf{c c}$ & Inside & cc & $\mathbf{F}$ & Signific. \\
\hline $\mathrm{CO}_{4}{ }^{2}$ & 21.90194 & 4 & 20.09806 & 49 & 14.16680 & 0.000002 \\
\hline $\mathrm{HCO}_{3}^{-}$ & 11.22676 & 4 & 40.77424 & 49 & 4.74269 & 0.006484 \\
\hline $\mathrm{Cl}^{-}$ & 12.89094 & 4 & 29.10907 & 49 & 5.75704 & 0.002426 \\
\hline $\mathrm{SO}_{4}{ }^{2-}$ & 41.04442 & 4 & 10.96658 & 49 & 46.78762 & 0.000000 \\
\hline $\mathrm{Ca}^{2+}$ & 42.70105 & 4 & 9.29895 & 49 & 45.71640 & 0.000000 \\
\hline $\mathrm{Mg}^{2+}$ & 24.64500 & 4 & 17.45500 & 49 & $\mid 18.46068$ & 0.000000 \\
\hline $\mathrm{Na}^{+}$ & 27.65270 & 4 & 14.44740 & 49 & 25.05594 & 0.000000 \\
\hline Mineralization,g/L & 29.86498 & 4 & 12.14602 & 49 & 41.99004 & 0.000000 \\
\hline
\end{tabular}

Fig. 6. A copy of the screen with the ANOVA results of the chemical composition of the Ingulets water as of $\mathbf{1 5 . 0 7}$ for the period from 1973 to 2019

Another way to determine the nature of clusters is to check the means for each cluster provided by the graph of means. Usually, this graph gives the best idea of the results (Fig. 7).

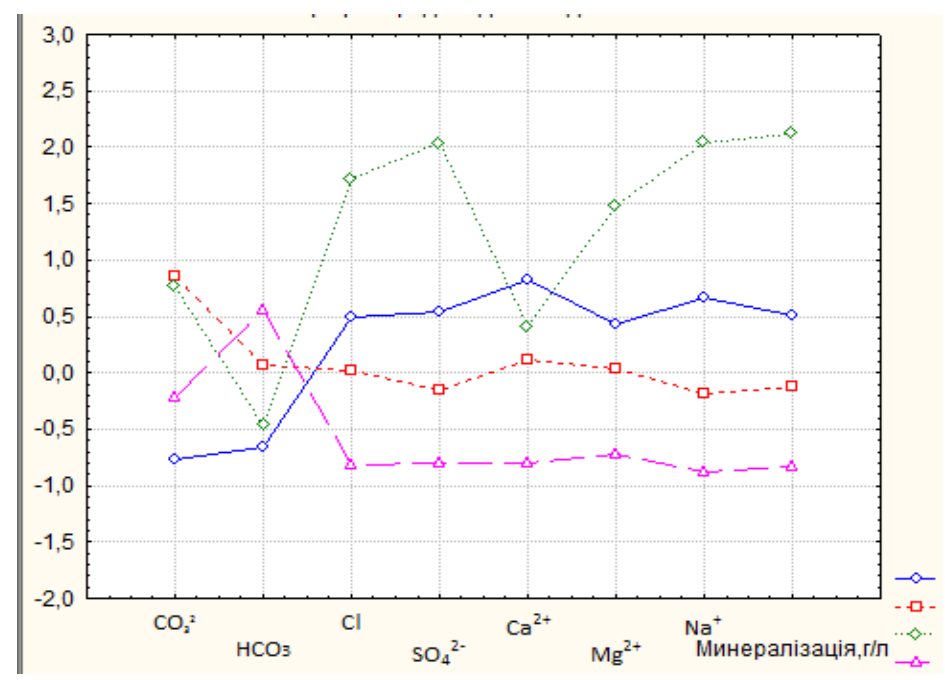

Fig. 7 The graph of the means of the ions content of the Ingulets irrigation water for the period of 1973-2019 (blue - cluster 1, red - cluster 2, green - cluster 3, purple - cluster 4) 
Loking at the graph line of the middle cluster 4, it is evident that the members of this cluster (in some years of the study) have higher rates of mineralization, anions $\mathrm{SO}_{4}{ }^{2-}, \mathrm{Cl}^{-}$, cations $\mathrm{Na}^{+}, \mathrm{Mg}^{2+}$ compared to the clusters $1,2,3$. The cluster 2 components characterized by a higher content of $\mathrm{CO}_{3}{ }^{2-}$; the elements of the cluster 1 have the lowest values of $\mathrm{CO}_{3}{ }^{2-}$, and the cluster 4 has the years with the lowest levels of $\mathrm{Cl}^{-}, \mathrm{SO}_{4}{ }^{2-}$, $\mathrm{Ca}^{2+}, \mathrm{Mg}^{2+}, \mathrm{Na}^{+}$and the highest level of $\mathrm{HCO}_{3}{ }^{-}, \mathrm{CO}_{3}{ }^{2-}$. Looking at the graphs of the means for the data of the mineralized water composition as of 15.05 and 15.07 of the studied years, we can observe that in different growing seasons the indices of ionic-salt composition of the water also behave differently.

For example, the dynamics of the graph for the period of 15th of May is characterized with sharp rapid fluctuations between the objects (Fig. 8).

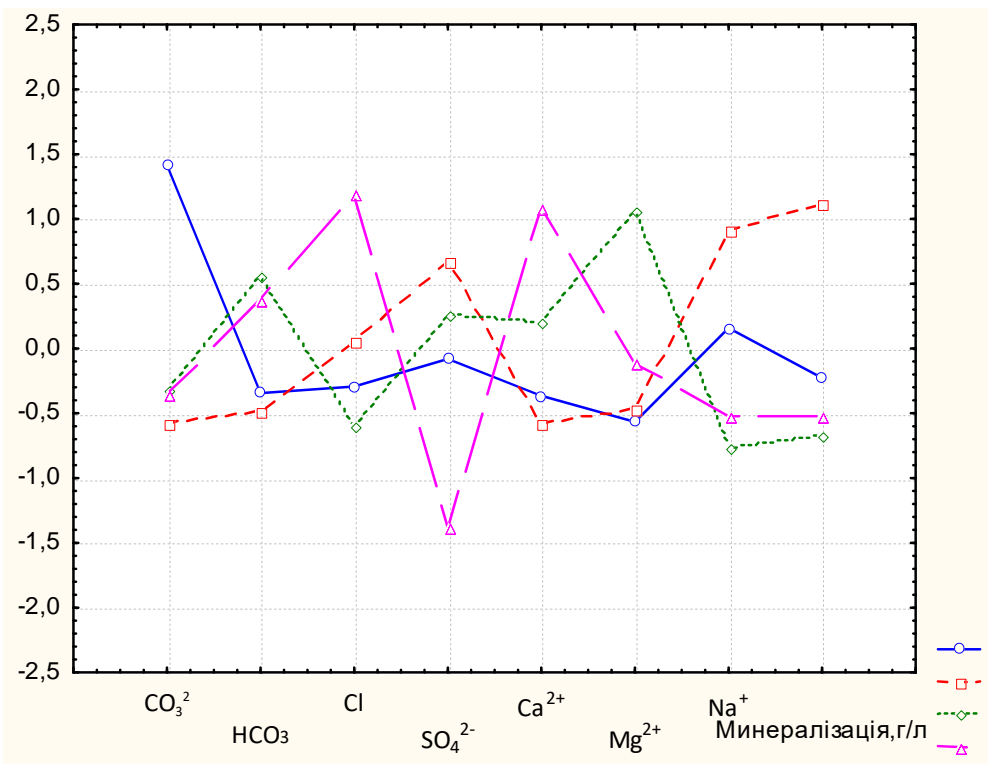

Fig. 8. Graph of the average chemical composition of the Ingulets water as of 15.05 for the period from 1973 to 2019 (blue - cluster 1, red - cluster 2, green - cluster 3 , purple - cluster 4 )

The graph of the means of the $1^{\text {st }}$ cluster differs from the other by the highest value of $\mathrm{CO}_{3}{ }^{2-}$, and the lowest value of $\mathrm{Mg}^{2+}$; the years from the $2^{\text {nd }}$ cluster have high $\mathrm{CO}_{3}{ }^{2-}$ values, the maximum of $\mathrm{SO}_{4}{ }^{2-}$, mineralization 
and $\mathrm{Na}^{+}$; the $3^{\text {rd }}$ cluster unites the years with the highest values of $\mathrm{Mg}^{2+}$ and $\mathrm{HCO}_{3}{ }^{-}$with the lowest mineralization, $\mathrm{Cl}^{-}$and $\mathrm{Na}^{+}$content; the $4^{\text {th }}$ cluster embraces the years with the maximum $\mathrm{Cl}^{-}$and $\mathrm{Ca}^{2+}$.

The graph of the averages as of 15.07 (Fig. 9) is more stable in its fluctuations: the years included in the cluster 1 have the highest rates of $\mathrm{SO}_{4}{ }^{2-}, \mathrm{Ca}^{2+}$, mineralization.

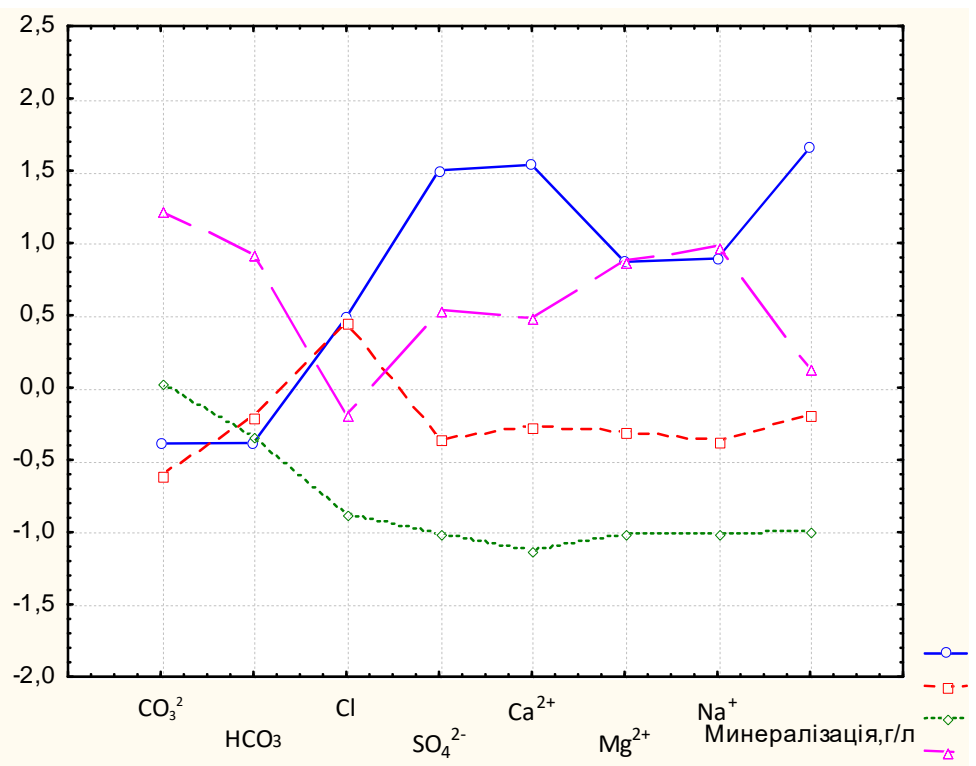

Fig. 9. Graph of the average chemical composition of the Ingulets water as of $\mathbf{1 5 . 0 7}$ for the period from 1973 to 2019

The members of the cluster 2 are characterized by the lowest level of $\mathrm{CO}_{3}{ }^{2-}$; in the cluster 4 there are the elements with the highest indices of $\mathrm{Cl}^{-}, \mathrm{SO}_{4}{ }^{2-}, \mathrm{Ca}^{2+}, \mathrm{Mg}^{2+}, \mathrm{Na}^{+}$, mineralization; and the cluster 4 has the highest $\mathrm{CO}_{3}{ }^{2-}$ and $\mathrm{Na}^{+}$. In the last step of the method of k-means, Statistica proposes to safe the classification of the data by clusters. It is very convenient and appropriate for further use of these data in other studies within other applications and information systems.

\subsection{The Dnipro irrigation water analysis}

The ionic-cationic composition of the irrigation water from the Dnipro River was also classified and analyzed by cluster analysis. 
According to the analysis of the hierarchical clustering tree formed by the program (Fig. 10), it can be assumed that the studied characteristics of the ionic-salt composition of the Dnipro water are formed in 5 natural clusters (1 cluster $-\mathrm{HCO}_{3}{ }^{2-} ; ; 2$ cluster $-\mathrm{Na}^{+}+\mathrm{K}^{+}, \mathrm{Ca}^{2+}, \mathrm{CO}_{3}{ }^{2-}$; 3 cluster $-\mathrm{pH}, \mathrm{SO}_{4}{ }^{2-} ; 4$ cluster $-\mathrm{Cl}^{-} ; 5$ cluster $-\mathrm{Mg}^{2+}$, mineralization). This distribution indicates the highest degree of interaction, a close relationship between $\mathrm{HCO}_{3}^{-}, \mathrm{Mg}^{2+}$ and mineralization.

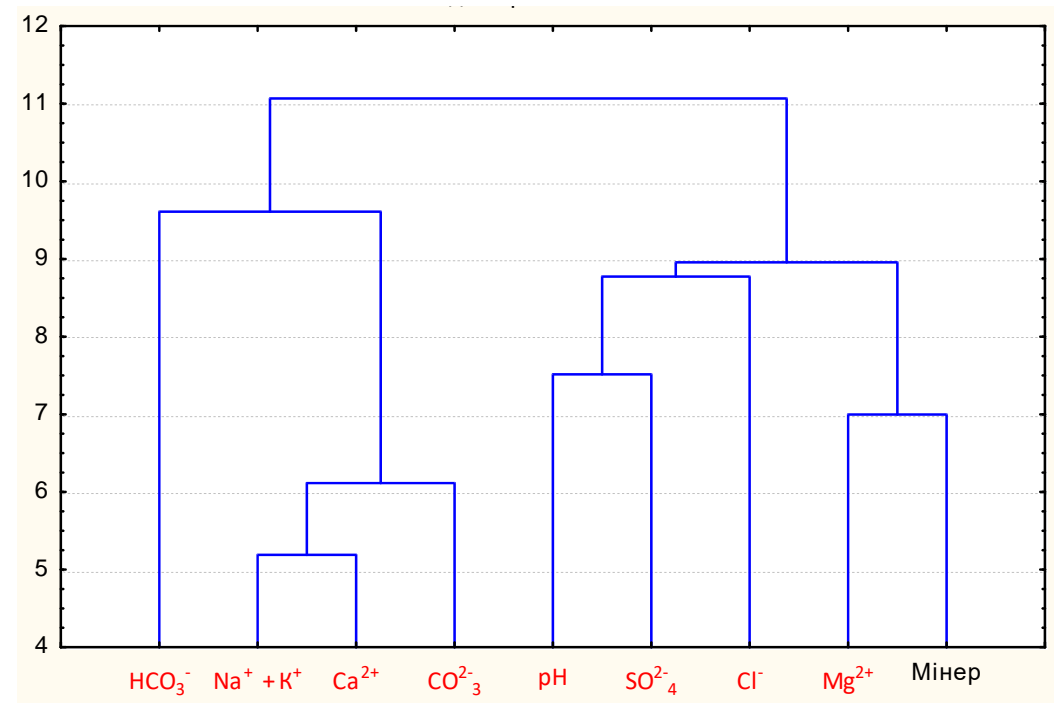

Fig. 10. The hierarchical model of the cluster analysis of the Dnipro water for the period of 1973-2019

Then, after clustering the Dnipro water by the method of k-means, we obtained the results of ANOVA. Based on the amplitude and significance levels of F-statistics, we can conclude that the variables $\mathrm{HCO}_{3}{ }^{-}$and $\mathrm{Mg}^{2+}$ are the most significant in the distribution of the objects by the clusters (Fig. 11). 
ANOVA (min_dnipro.sta)

\begin{tabular}{|c|c|c|c|c|c|c|}
\hline & Intra & cc & Inside & cc & $\mathbf{F}$ & Signific. \\
\hline Miner & 22.76751 & 4 & 19.24249 & 48 & 11.24615 & 0.000004 \\
\hline $\mathrm{CO}_{4}{ }^{2-}$ & 18.72754 & 4 & 24.27247 & 48 & 7.64472 & 0.000127 \\
\hline $\mathrm{HCO}_{3}^{-}$ & 29.72869 & 4 & 12.27141 & 48 & 24.01485 & 0.000000 \\
\hline $\mathrm{Cl}^{-}$ & 5.11775 & 4 & 46.88224 & 48 & 1.41821 & 0.280747 \\
\hline $\mathrm{SO}_{4}{ }^{2-}$ & 20.69974 & 4 & 21.40027 & 48 & 9.24216 & 0.000026 \\
\hline $\mathrm{Ca}^{2+}$ & 18.99244 & 4 & 24.00766 & 48 & 7.84205 & 0.000104 \\
\hline $\mathrm{Mg}^{2+}$ & 29.48208 & 4 & 12.51792 & 48 & 22.47441 & 0.000000 \\
\hline $\mathrm{Na}^{+}+\mathbf{K}^{+}$ & 22.87284 & 4 & 19.12717 & 48 & 11.46048 & 0.000004 \\
\hline pH & 22.96054 & 4 & 19.04946 & 48 & 11.45647 & 0.000004 \\
\hline
\end{tabular}

Fig. 11. A copy of the screen with the ANOVA results on the average chemical composition of the Dnipro irrigation water for the period from 1973 to 2019

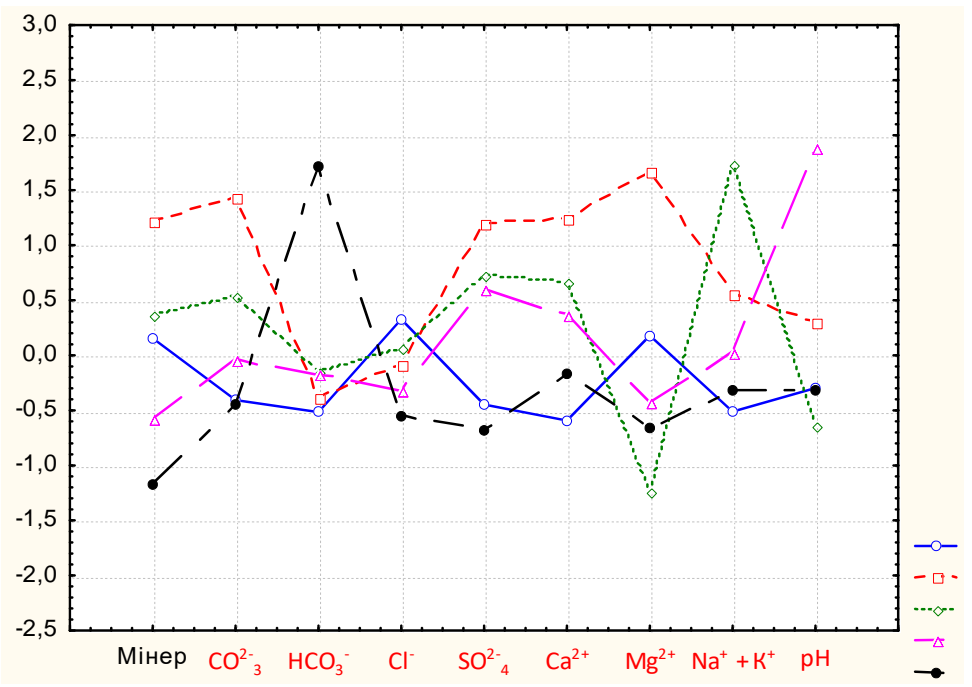

Fig. 12. Graph of the average chemical composition of the Dnipro irrigation water during the period of 1973-2019 (blue - cluster 1, red - cluster 2, green - cluster 3 , purple - cluster 4 , black - cluster 5) 
Analyzing the graph of the averages for the Dnipro irrigation water (Fig. 12), we can observe the highest values of $\mathrm{Cl}^{-}$in the elements of the cluster 1; the years of the cluster 2 have the highest levels of $\mathrm{CO}_{3}{ }^{2-}, \mathrm{Mg}^{2+}, \mathrm{SO}_{4}{ }^{2-}$, mineralization and $\mathrm{Ca}^{2+}$; in the 3 rd cluster there are components with the lowest $\mathrm{Mg}^{2+}, \mathrm{pH}$ and the highest $\mathrm{Na}^{+}+\mathrm{K}^{+}$; the cluster 4 includes the years with the highest $\mathrm{pH}$ content; and the elements of the cluster 5 are characterized by the lowest rates of mineralization, $\mathrm{CO}_{3}{ }^{2-}, \mathrm{Cl}^{-}, \mathrm{SO}_{4}{ }^{2-}$ and the highest $\mathrm{HCO}_{3}{ }^{-}$.

\subsection{Irrigation water quality and climate patterns}

The need for water for the yield and the quality of water for irrigation are two main factors that need to be considered in order to ensure proper water management to combat salinity. Proper irrigation restores soil water deficiency and avoids the use of wasteful and potentially harmful surpluses. Irrigation plus rainfall is required to prevent soil salinization. Soluble salts contained in irrigation water are concentrated in the soil solution as a result of soil evaporation and transpiration of plants ${ }^{31}$.

Using the information obtained as a result of perennial study, the tendency of interdependence between moisture supply by the years and dynamics of mineralization of irrigation water was analyzed.

Statistical analysis of the obtained data was performed using the capabilities of the modern information system Microsoft Office Excel using the correlation-regression method, which significantly accelerates the calculation process, and also allows to significantly increase the amount of processed data.

During modeling of the water regime of the soil, three main meteorological indices should be taken into account: air temperature, relative air humidity, precipitation. Air temperature, relative air humidity is taken according to the nearest weather station or indices from the Internet - for example from the site https://rp5 ${ }^{32}$. Precipitation should be measured with rain gauges, which are installed near or directly on the irrigated fields, then they are taken under consideration in the calculation of the water use. Air temperature and precipitation for the year are taken into account in the following order: for January - March and October -

31 Концепція відновлення та розвитку зрошення у південному регіоні України / за науковою редакцією д.т.н., академіка М. І. Ромащенка. К. : ЦП «Компринт», 2014. 28 с.

32 Алов А. С. Факторы эффективности удобрений. Часть II Агрофизикохимические факторы. М., 1967. 1. 
December as the sums by ten-day periods for each of these three months; for April - September they are assessed daily for the periods of five days, ten days and months. During rainfall, not all the precipitation that falls has time to get into the soil, and a certain part of it is lost on runoff and evaporation. In this regard, in the practice of irrigated agriculture, rainfall should be considered by two parameters: first, the total amount of precipitation, and secondly, their share, which was absorbed by the soil. Relative air humidity is taken into account for the period April September on the daily basis, with the calculation of the average for the periods of five days, ten days, months - in ascending order.

Water use for past pentads ( 5 days) is calculated as the difference between total evaporation $\mathrm{E}$ and precipitation $\mathrm{P}$ in $\mathrm{mm}$. The difference "E - P" shows how the moisture reserves in the field have changed under the influence of weather conditions. When in the calculation period "E" was greater than "P" - moisture reserves decrease by this value, when "E" is less than "P", on the contrary, moisture reserves increase. To facilitate the calculation of total evaporation, we set the calculated values of $E_{1}$ in the temperature range from 5 to $40^{\circ} \mathrm{C}$ (every $0.5^{\circ} \mathrm{C}$ ) and relative humidity - from 30 to $90 \%$ (over every $5 \%$ ). The calculation of the total evaporation and water use by an individual crop in the rotation is performed using both biologically optimal and water-saving irrigation regimes taking into account the levels of groundwater.

Using the obtained results of the calculations throeugh the method of correlation analysis, graphs were formed that reflect the patterns between the deficit of evaporation and mineralization of irrigation water in dry and moderately dry years as of 15.05 (Fig. 13).

The studied indices show a high degree of negative (inverse) connection. Thus, the correlation coefficient in the first block as of 15.07 ranged from 0.76 to 0.78 (Fig. 14). That is, it allows us to conclude that the drier the natural weather conditions (dry year) for crops is, the higher the level of the mineralization of the irrigation water is.

And in humid years, on the contrary, there is no such trend (Fig. 15) for the Ingulets water with a correlation coefficient of -0.01 , for the Dnipro irrigation water (Fig. 16) with a correlation coefficient of 0.24. 


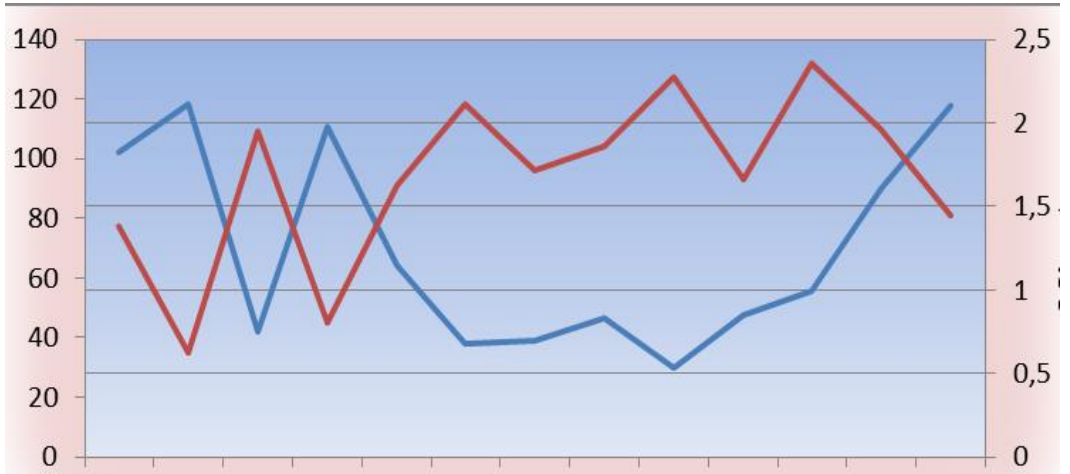

1973197719781980198519871988199119971998200120112015

Fig. 13. Dependence of the mineralization of the irrigation water from the river Ingulets on the evaporation deficit in dry and moderately dry years of the study as of $\mathbf{1 5 . 0 5}$ for winter wheat (left scale - Evaporation Deficit, mm; right scale Mineralization, g/L; blue line - mineralization; red line - evaporation deficit)

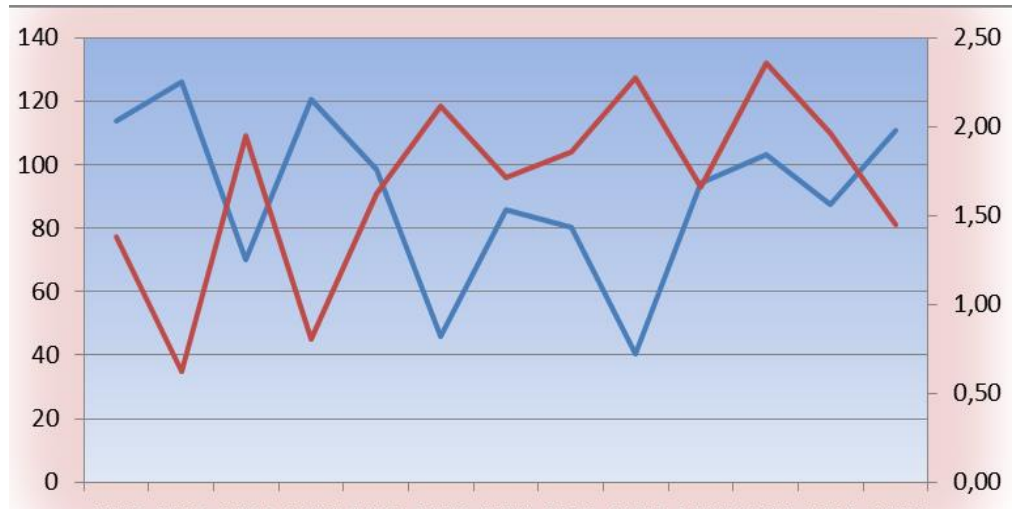

1973197719781980198519871988199119971998200120112015

Fig. 14. Dependence of the mineralization of the Ingulets irrigation water on evaporation deficit in dry and moderately dry years of the study as of $\mathbf{1 5 . 0 7}$ for wheat (left scale - Evaporation Deficit, mm; right scale - Mineralization, g/L; blue line - mineralization; red line - evaporation deficit) 


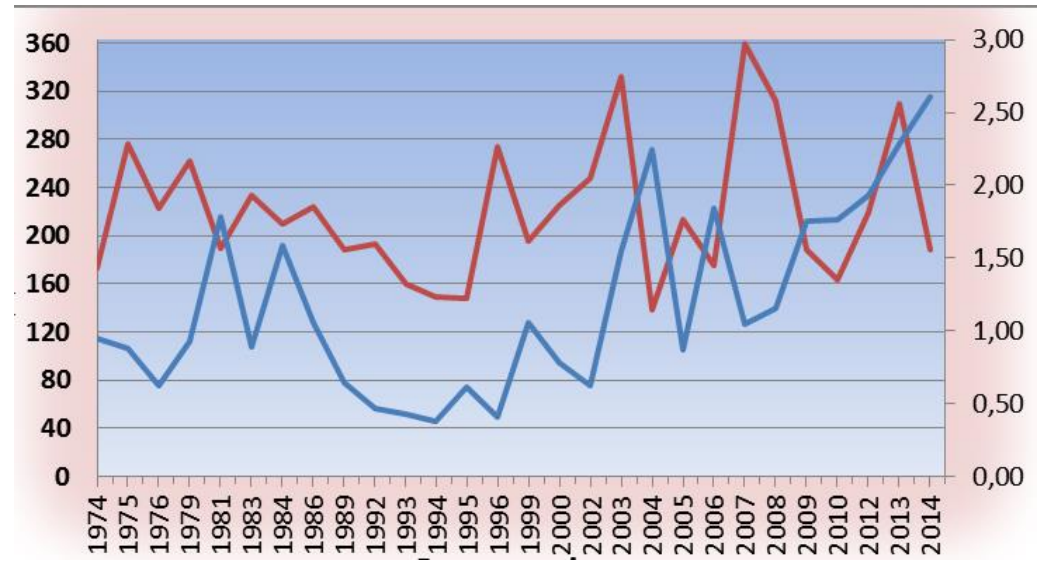

Fig. 15. Dynamics of the mineralization and deficiency of evaporation of the irrigation water of the Ingulets River in humid and moderately humid years of the study as of $\mathbf{1 5 . 0 7}$ for wheat (left scale - Evaporation Deficit, $\mathbf{m m}$; right scale - Mineralization, g/L; blue line - mineralization; red line - evaporation deficit)

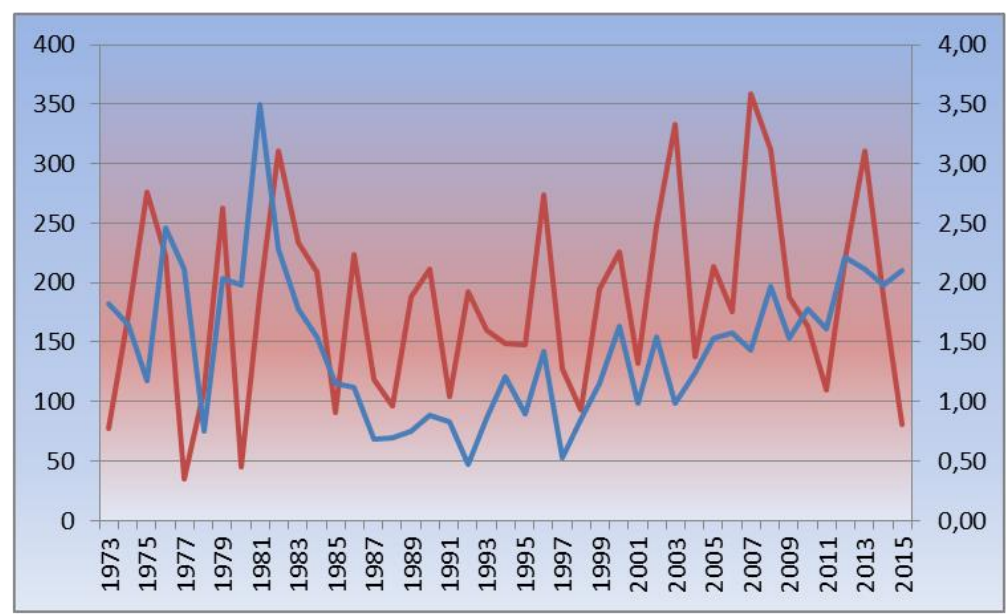

Fig. 16. Dynamics of the mineralization (average values for vegetation periods) and deficit of evaporation of the irrigation water of the Dnipro River in the years of the study for winter wheat (left scale - Evaporation Deficit, mm; right scale - Mineralization, g/L; blue line - mineralization; red line - evaporation deficit) 
Using the data of cluster analysis of the ionic-salt composition of the irrigation water generated in the program Statistica, it is possible through modeling visual graphs, charts, histograms in Excel to track various dependences on specific variables (indices) both for research and at the production level - to enhance irrigation productivity.

For example, Figure 17 shows the dynamics of $\mathrm{pH}$ and mineralization of the Dnipro irrigation water in the clusters $1-$ (a), 2 - (b), $3-$ (c), $4-(\mathrm{d})$.

Analyzing the data on the hydrogen power of the solution acidity, which determines the ability of a plant to absorb nutrients, and mineralization data, it is possible, as well as taking into account the dynamics of the average chemical composition of the Dnipro irrigation water by the years of the study, to distribute the $\mathrm{pH}$ indices in dependence on the clusters classification. If the years from the cluster 1 had a $\mathrm{pH}$ of neutral water, the maximum $\mathrm{pH}$ of the components of the cluster 4 reached 8.40 , of the cluster $2-8.44$, and of the cluster 3 in general it was 8.68 , which corresponds to an alkaline environment.

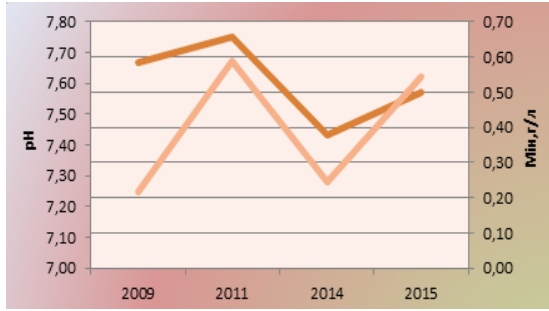

a) Cluster 1

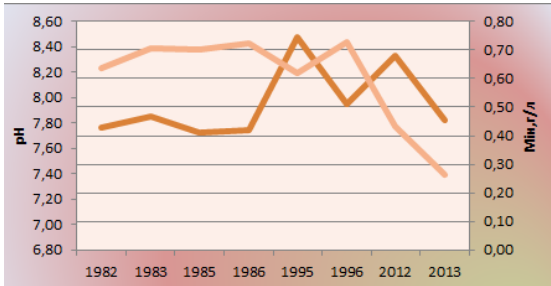

b) Cluster 2

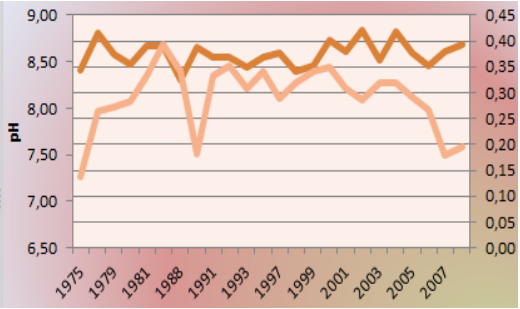

c) Cluster 3

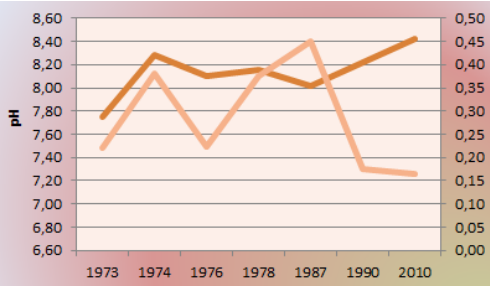

d) Cluster 4

Fig. 17. Dynamics of the pH level and mineralization (average values for vegetation periods) of the Dnipro irrigation water by the years of the study with division into clusters (red line - mineralization, pink line $-\mathbf{p H}$ index) 
Determination of the $\mathrm{pH}$ index for irrigation water is a very important factor, because it has a very important effect on plants: some plants cannot withstand acidic soils, others grow and develop well. The $\mathrm{pH}$ index affects the growth of the root system, its permeability to nutrients, shifts the correct ratio in the plant uptake of cations and anions, reduces soil fertility and the harmful effects of hydrogen ions on the mineral part of the soil. Deficiency of absorbed calcium and magnesium in the soil causes a sharp deterioration of its physical and physicochemical properties.

Analysis of the $\mathrm{pH}$ index for the studied years in terms of their clusters provides more data to decide on the accuracy of the need to determine chemical reclamation (liming, gypsum application, etc.).

Although there is no correlation between the mineralization and $\mathrm{pH}$ of the irrigation water in this case, the graph curves in each cluster have similar dynamics, which provides prerequisites for the conclusion of the interaction between the cationic-anionic composition of the irrigation water and its $\mathrm{pH}$ level.

\section{CONCLUSIONS}

1. According to the results of our study and calculations, the effectiveness of the application of cluster analysis methods implemented in the modern software and information complex Statistica 6.1 is proved. Clustering of the cationic-anionic composition of the Ingulets and Dnipro water for the period from 1973 to 2019 revealed that the irrigation water from the Ingulets irrigation system has a concentration of toxic ions in chlorine equivalents in the range of $25-42 \mathrm{meq} / \mathrm{dm}^{3}$, the ratio of sodium to the sum of alkaline cations was $41-47 \%$. The analysis of the large series of experimental data provides a wide range of possibilities for the formation of hierarchical models-dendrograms of cluster analysis with the classification of the studied years by individual clusters (groups) and the definition of differentiation between the groups.

2. The method of clustering of k-means provided the opportunity to find intergroup dispersions by the studied ionic-salt composition of the Ingulets and Dnipro irrigation water, which are compared with intragroup dispersions to decide whether the averages for individual variables in different sets are significantly different for the periods of 15.07, 15.09 for 1973-2019. Based on the amplitude (levels of significance) of F-statistics, the method of $\mathrm{k}$-means helped to find the significance of variables of cationic-anionic composition in solving the question of the distribution of objects in the 
clusters, to form graphs of the averages to determine the nature of clusters and check averages provides the best idea of the results of mineralization in terms of growing seasons. According to the results of the calculations, a hierarchical clustering tree was formed, which allowed to distribute the indices of ion-salt composition by 4 natural clusters (cluster 1 mineralization, $\mathrm{Ca}^{2+}$; cluster $2-\mathrm{Na}^{+}, \mathrm{Mg}^{2+}, \mathrm{SO}_{4}{ }^{2-}$; cluster $3-\mathrm{Cl}^{-}$; cluster $4-\mathrm{HCO}_{3}{ }^{-}, \mathrm{CO}_{3}{ }^{2-}$ ).

3. According to the analysis of the hierarchical clustering tree formed by the program, it is found out that the studied characteristics of the ionic-salt composition of the Dnipro water are distributed among five natural clusters (cluster 1 - containing hydrocarbons $\mathrm{HCO}_{3}{ }^{-}$; cluster $2-$ containing sodium, potassium, calcium and carbonates $\mathrm{Na}^{+}+\mathrm{K}^{+}, \mathrm{Ca}^{2+}$, $\mathrm{CO}_{3}{ }^{2-}$; cluster 3 - containing sulphur oxide $\mathrm{SO}_{4}{ }^{2-}$ and $\mathrm{pH}$; cluster $4-$ containing $\mathrm{Cl}^{-}$; cluster 5 - containing $\mathrm{Mg}^{2+}$, mineralization). This distribution indicates the highest degree of interaction and the maximum level of mathematical relationships between the indicators of hydrocarbons $\mathrm{HCO}_{3}{ }^{-}, \mathrm{Mg}^{2+}$ and mineralization.

4. The application of the above methods in the experiments, implemented in Statistica and Excel, allowed us to draw many useful conclusions for the use of knowledge in agro-ameliorative production practice of crop production to create a scientific basis for environmental safety of irrigated water and land in southern Ukraine. Using the obtained results and correlation analysis, graphs were formed that reflect the patterns between evaporation deficiency and mineralization of the irrigation water in dry and moderately dry years. The studied indices showed a high degree of negative relationship with the correlation coefficients - minus 0.76-0.78.

5. The developed models should be used for timely management decisions, including irrigation regime, watering and irrigation rates, quality of irrigation water, tracking the dynamics of the cationic-anionic composition of water and its mineralization, the dynamics and degree of secondary salinization and alkalinization of soils, doses and types of ameliorants. The dependences of $\mathrm{pH}$ level and mineralization of the Dnipro irrigation water are distributed by four clusters. It should be mentioned that in the first cluster the $\mathrm{pH}$ of the water had a reaction close to neutral. The maximum $\mathrm{pH}$ level of the components of the second cluster reached 8.40 , of the third one -8.44 , and of the fourth one -8.68 , which corresponds to an alkaline environment. 


\section{SUMMARY}

Irrigation is one of the major factors in agricultural production sustainability, while its efficiency is strongly dependent on the water quality. The main agronomic criteria for evaluation of water suitability for irrigation are $\mathrm{pH}$, mineralization, ions content and proportion. There are two main sources of irrigation water in the South of Ukraine, namely, the Ingulets and Dnipro river water. We applied cluster analysis approach to the classification of these waters by the main agronomic criteria. Cluster analysis of the ionic composition of the Ingulets and Dnipro water for the historical period of 1973-2019 revealed that the irrigation water of the Ingulets system has a concentration of toxic ions in the range of $25-42 \mathrm{meq} / \mathrm{dm}^{3}$, the ratio of sodium to the sum of alkaline cations is $41-47 \%$, making it is limited suitable for irrigation, while the Dnipro river water is much safer. The analysis of the data set on the water quality allowed to create hierarchical dendrograms with the classification of the studied years by individual clusters and the definition of differentiation between the groups in the irrigation water from the studied sources. Besides, we have studied the effect of climate patterns on the water quality. The results of the study testify about negative strong correlation between evaporation deficiency and mineralization of the irrigation water in dry and moderately dry years $(\mathrm{R}=-0.76-0.78)$. The developed mathematical models and cluster analysis results could be used for timely decisions on irrigation management, irrigation rates, would be helpful in tracking the dynamics of the ionic composition of the water, the hazards of secondary salinization and alkalinization of the irrigated lands.

\section{References}

1. Оцінка i прогноз якості земель: навчальний посібник / С. Ю. Булигін, А. В. Барвінський, А. О. Ачасова, А. Б. Ачасов. Харків : Вища школа, 2008. 237 с.

2. Удобрення польових культур при інтенсивних технологіях вирощування / за ред. А. Я. Буки, Г. Г. Дуди. К. : Урожай, 1990. $208 \mathrm{c}$.

3. Водне господарство в Україні / За ред. А.В. Яцика, В.М. Хорєва. К.: Генеза, 2000. 456 с.

4. Грунтознавство / за ред. Д. Г. Тихоненка. К., 2005. С. 122-127. 
5. ДСТУ 4289:2004. Якість грунту. Методи визначання органічної речовини.

6. Кисель В. Д. О генезисе солонцеватых почв Украины. Почвоведение. 1981. № 12. С. 10-12.

7. Балабанова Л. В. SWOT-аналіз - основа формування маркетингових стратегій: Навчальний посібник. 2-ге вид., випр. і доп. (Вища освіта XXI ст.) К. : Знання, 2005. 301 с.

8. Сидоренко О. І., Бабанін В. В., Морозов О. В. Екологоагромеліоративний моніторинг зрошуваних земель. Херсон : Колос, 2013. $152 \mathrm{c}$.

9. Справочник агрогидрологических свойств почв Украинской ССР / под ред. А. А. Мороз. Ленинград: Гидрометеорологическое издательство, $1965.550 \mathrm{c}$.

10. Коваленко П. І., Михайлов Ю. О. Раціональне використання води при зрошенні. К. : Аграрна наука, 2000. 215 с.

11. Медведєв В. В., Чесняк Г. Я., Полупан М. І. та ін. Родючість грунтів: моніторинг та управління. К. : Урожай, 1992. 248 с.

12. Методические указания по определению нитрификационной способности почв. М. : ВПНО «Сельхозхимия», 1984. 16 с.

13.Жигулина Е. В., Максименко В. П., Волчкова Т. Л. Повышение плодородия почв на орошаемых землях. Методы и технологии комплексной мелиорации и экосистемного водопользования : Сб. науч. трудов / Под ред. акад. РАСХН Б. М. Кизяева. М. : Россельхозакадемия, 2006. С. 426-442.

14. Тимчук В. М. Моніторинг ринку об'єктів права інтелектуальної власності в галузі рослинництва. Вісник аграрної науки. 2007. № 10. С. 30-32.

15.Кудеяров В. Н., Башкин В. Н., Кудеярова А. Ю., Бочкарев А. Н. Экологические проблемы применения минеральных удобрений. М. : Наука, 1984. 214 с.

16. Ковда В. А. Происхождение и режим засоленных почв. М.-Л. : АН СССР, 1979. С. 52-59.

17.Балюк С. А., Верніченко Г. А. Концепція екологічного ризику деградації грунтового покриву України. Вісник аграрної науки. 2002. № 6. С. 5-11.

18.Грунтознавство 3 основами геології : [навч. посіб] О. Ф. Ігнатенко, М. В. Капштик, Л. Р. Петренко, С. В. Вітвицький. К. : Оранта, 2005. 648 c. 
19.Справочник по орошаемому земледелию / под ред. В. И. Остапова. 2-е изд., перераб. и доп. К. : Урожай, 1989. 256 с.

20.Бендиков М. А., Джамалай Е. В. Интеллектуальный капитал развивающейся фирмы: проблемы идентификации и измерения. Менеджмент в России и за рубежом. 2001. № 4. С. 3-24.

21.Качинский Н. А. Изучение физических свойств почв и корневых систем растений. М. : Сельхозгиз, 1930. 101 с.

22.Салин В. Н. Социально-экономическая статистика: практикум / под ред. В. Н. Салина, Е. П. Шпаковской. М. : Финансы и статистика, 2012. 192 с.

23. Сиденко А. В., Попов Г. Ю., Матвеева В. М. Статистика: учебник. М. : Изд-во «Дело и сервис», 2009. 464 с.

24.Финансовая статистика: учеб. пособие / под ред. Т. В. Тимофеевой. М. : Финансы и статистика, 2008. 480 с.

25.Харченко О. В. Основи програмування врожаїв сільськогосподарських культур : навчальний посібник / за ред. академіка УААН В. О. Ушкаренка [2-е вид., перероб. і доп.]. Суми: Університетська книга, 2003. 296 с.

26.Балюк С. А., Новікова Г. В., Гаврилович Н. Ю. Використання солонцевих грунтів України. Вісник аграрної науки. 2001. № 10. С. $12-15$.

27.Дорогунцов С. I., Чернюк Л. Г., Борщевський П. П. Соціально-економічні системи продуктивних сил регіонів України. Рада по вивч. продукт. сил України НАН України. К. : Нічлава, 2002. $691 \mathrm{c}$.

28.Балюк С. А. Внесення мінеральних добрив і меліорантів 3 водою при дощуванні. Довідник працівника агрохімслужби / за ред. Б. С. Носкова. К. : Урожай, 1991. С. 100-104.

29.Біляєва I. М. Наукове обгрунтування систем удобрення зрошуваних агрофітоценозів з моделюванням вмісту органічних та неорганічних сполук. Матеріали Міжнародної науково-практичної конференції «Управління водними ресурсами в умовах змін клімату», присвяченої Всесвітньому дню води (21 березня 2017 р.). К. : ЦП «КОМПРИНТ», 2017. С. 156-157.

30.Григоров М. С. Высокоэффективное внутрипочвенное орошение. Известия Нижневолжского агроуниверситетского комплекса. 2010. № 1(17). С. 3-5. 
31.Концепція відновлення та розвитку зрошення у південному регіоні України / за науковою редакцією д.т.н., академіка М. I. Ромащенка. К. : ЦП «Компринт», 2014. 28 с.

32. Алов А. С. Факторы эффективности удобрений. Часть II Агрофизико-химические факторы. М., 1967. 1.

Information about the authors:

Biliaieva Iryna Mykolaivna, Doctor of Agricultural Sciences, Senior Researcher, Head of the Department of Transfer of Innovations, Marketing and Economic Studies Institute of Irrigated Agriculture of National Academy of Agrarian Sciences of Ukraine Naddnipryanske sett., 73483, Kherson region, Ukraine

Lykhovyd Pavlo Volodymyrovych, Candidate of Agricultural Sciences, Department of Transfer of Innovations, Marketing and Economic Studies Institute of Irrigated Agriculture of National Academy of Agrarian Sciences of Ukraine Naddnipryanske sett., 73483, Kherson region, Ukraine 